The organism in question forms non-liquefying porcelain-like white or cream-coloured colonies on gelatine, and behaves exactly like a Schizomycete when grown on Agar, Potato, and in Broth, Milk, and other media. It does not ferment glucose, and when examined in the usual way under the microscope it appears as a Bacillus-like form 2-4 $\mu$ long, and about I $\mu$ thick, or as 'cocci' about I $\mu$ diameter staining normally by Gram's and other methods, without movements, and with no known endogenous spores.

Nevertheless, on tracing its development even in alkaline gelatine, under the one-twelfth and one-twentieth immersion, it is found to branch and to grow by acropetal apical growth. When a short branch-system has been formed, the whole segments up entirely into joints like Bacilli, which eventually separate at the septa, and are at length cut up into shorter and shorter portions almost like micro-cocci or extremely short Bacteria.

From all the evidence there can be no doubt that we have here an öidial form of a true Fungus, and not a Schizomycete at all, and it raises some interesting questions concerning alleged forms of 'branching' Bacteria, and the very various origins of the different micro-organisms commonly grouped together as 'Bacteria.' In particular, it is an excellent case in point, illustrating the fact that an organism must not be assumed to be a Schizomycete merely because it is small, grows on gelatine, and can be stained by the methods of bacteriology.

H. MARSHALL WARD.

\title{
ON A NEW FORM OF FRUCTIFICATION IN SPHENO-
} PHYLLEAE'. - The author gave an account of Bowmanites Römeri, the fructification of a new member of the Sphenophylleae. It is only recently that the work of Williamson and Zeiller ${ }^{2}$ has given us a clearer insight into the structure of the fructifications of Sphenophyllum, which consist of successive and similar whorls of leaves arranged in a spike, the leaves of each whorl being coherent at the base. The numerous sporangia are seated on the inner and upper side of this

1 Abstract of a paper read before the Botanical Section of the British Association at Ipswich. For the full illustrated description see Jahrbuch der K. K. Geolog. Reichsanstalt, Wien, I895, Band 45, Heft 2.

${ }^{2}$ See Williamson, Organization of Fossil Plants of Coal-measures, Parts V and XVIII, Phil. Trans. I874 and I89I ; Williamson and Scott, Further Observations on Organization, \&c., Part I, Phil. Trans. I894; Zeiller, L'Appareil fructificateur des Sphenophyllum, Mém. II de la Soc. Géol. de France, I893. 
sheath-like portion of the whorl, ranged in two or three concentric circles between each two whorls of leaves. Each sporangium is borne on a thin stalk, from the apex of which it is suspended, bending over towards the axis. At the bend, just where the stalk passes over into the base of the sporangium, we find a crested ridge, characterized by large thick-walled epidermal cells, like those of an annulus. Zeiller has come to the same conclusions from studying specimens preserved as impressions, which Williamson arrives at from the sections of his Bowmanites Dawsoni, and has declared the two forms to be identical, both belonging to Sphenophyllum cuneifolium. It seems, however, that this specific identification will not hold good.

The author found exactly the same structure in the original specimen of Borwmanites germanicus, Weiss, and in a fruit-spike of Sphenophyllum emarginatum in the Dresden Museum.

A different structure, however, is exhibited by a fragment of a cone, which the author has named Bowmanites Römeri, and which was found by Ferdinand Römer on the refuse-heaps of the Nieldzielisko Colliery in Cracow. In the first place, the superposition of the successive whorls forming the spike could here be determined with certainty. It could further be shown that several successive circles of sporangium-pedicels are inserted upon each whorl. While, however, in all forms of Sphenophyllum previously investigated, only a single sporangium is borne on the recurved end of the pedicel, in the new form two sporangia are suspended from a scale-like enlargement at the apex of each pedicel. In all other points of its organization there is the greatest similarity with the specimens already known.

H. GRAF ZU SOLMS-LAUBACH, Strassburg.

\section{PRELIMINARY NOTE UPON THE STRUCTURE OF} BACTERIAI CELLS ${ }^{1}$.- In this preliminary paper, which is a continuation of some work already referred to in the Annals of Botany ${ }^{2}$, a short account is given of observations which have been in progress for some time upon the structure of bacterial cells, especially with reference to the question of the presence or absence of a nucleus. It is, I think, generally admitted that the structure of the bacterial cell is of a simpler kind than that of other cells; but nearly all observers agree in stating that some kind of structure akin to the nucleus is

1 Abstract of a paper read at the Ipswich meeting of the British Association before the Botanical Section.

${ }^{2}$ Annals of Botany, Vol. v, p. 5 I3 3 . 


\section{$2 \mathrm{BHL}$ Biodiversity Heritage Library}

Solms-Laubach, Hermann. 1895. "On a new form of fructification in Sphenophylleae." Annals of botany 9, 658-659.

https://doi.org/10.1093/oxfordjournals.aob.a090761.

View This Item Online: https://www.biodiversitylibrary.org/item/233478

DOI: https://doi.org/10.1093/oxfordjournals.aob.a090761

Permalink: https://www.biodiversitylibrary.org/partpdf/318400

\section{Holding Institution}

Smithsonian Libraries

\section{Sponsored by}

Biodiversity Heritage Library

\section{Copyright \& Reuse}

Copyright Status: Not in copyright. The BHL knows of no copyright restrictions on this item.

This document was created from content at the Biodiversity Heritage Library, the world's largest open access digital library for biodiversity literature and archives. Visit BHL at https://www.biodiversitylibrary.org. 